\title{
A Scenario of the Canadian Generation Y Consumers' Behavioral Usage on the Internet
}

\author{
Allen Lim Chong Guan', Goi Chai Lee ${ }^{2}$, Peter Dell ${ }^{3}$ \\ ${ }^{1}$ East Stroudsburg University, USA \\ ${ }^{2,3}$ Curtin University, AUSTRALIA
}

https://doi.org/10.18034/abr.v11i2.580

\begin{abstract}
The main purpose of this research is to explore how Canadian Generation Y consumers' behavioral use the Internet. This research explores to determine the factors and variables that can increase the number of Canadian Generation Y consumers' behavior using Canadian small businesses' retail websites. This provides information on how small business retailers are able to plan strategies and tasks to engage them. Research question is to gather qualitative data from Canadian Generation Y consumers' on their daily Internet and online shopping activities, and security and privacy on the Internet. The rationale behind the research objectives is to better understand Canadian Generation Y's behavioral usage of Canadian small businesses' retail websites. As it is imperative for retail websites to be an intrinsic part of the Internet, it is therefore important to understand Canadian Generation Y's behavioral usage of the Internet as well. This research makes a distinct contribution to the knowledge of the subject matters in the areas of Generation Y, small businesses, and the activities in the internet that are applicable to academicians and practitioners. This is the first time that research has been conducted specifically based on Canadian Generation Y consumers' behavioral usage and activities of Consumers on the Internet.
\end{abstract}

Key words: Young Generation, Behavioral Usage, Canadian Consumer, Internet

\section{INTRODUCTION}

Small enterprises in Canada have been making inroads into Canadian society by improving the overall quality of life for its citizens. Having said that, there is still room for improvement in terms of the development and progress of small enterprises in Canada, particularly in the manufacturing sector. Since 2015, small businesses have employed 8.2 million people in Canada, accounting for 70.5 percent of the entire private sector. As a result, small businesses have made major contributions to the growth and stability of the country's economy (Innovation, Science and Economic Development Canada, 2016). At the end of 2015, there were 1.14 million small firms (with one to ninety employees), accounting for 97.90 percent of all employer businesses in the country (Innovation, Science and Economic Development Canada, 2016).

According to a poll conducted by the Royal Bank of Canada in 2013, only 46 percent of small businesses in Canada have a website, and 48 percent of those enterprises do not have e-commerce capabilities (McKinnon, 2013). While at the same time, 38 percent of small firms with e-commerce capability produce 25 percent of their total sales over the internet (McKinnon, 2013). This demonstrates that small firms in Canada have not completely capitalized on the opportunities presented by the Internet. On-line commerce has the potential to expand the geographical reach of retailers and consumers, therefore increasing the range of products available and lowering the cost of doing business (Gomez-Herrera, Martens and Turlea, 2014).

Canadians visited 3731 webpages on average per month in 2013, the greatest number of webpages visited anywhere in the globe (CIRA Factbook, 2014). At the same time, Canadians spent an average of 41.30 hours a month on the Internet in 2013, placing those second only to Americans in terms of monthly Internet usage (CIRA Factbook, 2014). Households with several Internetconnected devices (including desktop computers (62 percent), laptop computers (74 percent), and wireless portable devices $(59 \%)$, account for 69 percent of all Internet-connected households (Statistics Canada, 2013). 
As reported by Statistics Canada (2014), Canadians made purchases of products and services from online merchants worth a total of C $\$ 7.7$ billion in 2012, an increase from $\mathrm{C} \$ 6.6$ billion in 2011. The increase was caused by an increase in the number of consumers who purchased online and in greater quantities. However, according to Yousefi and Tang (2012)'s empirical research, security is still the most pressing worry when it comes to using the Internet for business purposes. Credit card transactions and privacy violations may, however, become less of a worry with the arrival of thirdparty payment verifiers, such as PayPal.

If we want to increase the confidence of Generation $\mathrm{Y}$ in the websites of small Canadian businesses in the future, we must take more steps to ensure security and privacy, as well as to build trust with those businesses. The cost of Internet connection in Canada continues to be prohibitively expensive, and the Canadian federal government must issue additional Internet Service Provider (ISP) licenses in order to improve competition among ISPs and, as a result, lower the cost of Internet access. Still, small Canadian businesses are rapidly and progressively expanding their sales channels to include the Internet as part of their entire strategy, and this is particularly true for small businesses.

The embracing of Internet commerce may vary due to different levels of technological, cultural, economic, social, and other developments. Internet technology is changing the introduction of converging technologies such as mobile Internet and Internet television, to name a few. As accessing the Internet using mobile devices is becoming more ubiquitous, more people, at the same time, may find it more convenient to use these devices to purchase online. Retailers may have to redesign their advertisement layouts due to the small size of the screen of mobile devices. As Internet television becomes cheaper in the future, more people are expected to purchase online using such means. As such, retailers need to realign their marketing strategies to compete with television airtime.

The insights into how Generation Y'ers use the Internet, the kind of website design features and attributes they prefer, and the concerns they feel about trust and security, can all be channelized to create a better connection with them. The Canadian Generation Y consumers are comfortable with using the Internet and online shopping based on their Effort Efficiency (EE) and Facilitating Conditions (FC) scores.

\section{Methodology}

This section covers the data collected from personal interviews in relation to Research Question. This question pertains to how the Canadian Generation $\mathrm{Y}$ consumers carry out their activities on the Internet.

\section{Research Question}

How do Canadian Generation Y consumers carry out their behavioural usage on the Internet?
The qualitative data was collected from 30 interviewees and is organised on the basis of themes. Pseudonyms are used to protect individual identities.

Further, in line with ethical approval guidelines, the interviewees must remain anonymous with the pseudonyms used to denote their data. The data collected is grouped into themes and keywords that provides evidence to support the research model. More specifically, by triangulating the qualitative data with the quantitative data, a greater insight and understanding of the research phenomena can be achieved. In relation to this study, by extracting the data from content analysis, the opinions of the Canadian Generation $Y$ and the complex issues that are interrelated with them can be better studied. Through the process of comparing similarities and differences, the researcher can better understand the factors that affect the usage of Canadian small business retail websites by Canadian Generation Y.

\section{Qualitative Data Analysis}

\section{Free Time}

Based on the data collected from personal interviews, it can be said that the Canadian Generation $\mathrm{Y}$ is very active socially and is "full of life" and values time spent with family and friends, with good knowledge on how to have a worklife balance. They like socialising with friends and family, reading from physical and online copies, surfing the Internet, taking care of children, chatting online, watching movies, exercising, watching television, assembling things, house cleaning, online gaming, shopping, travelling, golfing, playing with remote control helicopters, biking, gardening, renovating the house, playing games, online shopping, listening to music, singing, cooking, playing the guitar and the piano, and church activities. Facebook seems to be a very popular social media platform. Because of their activities, they can relax, enjoy exercising, and have a sense of belonging. Online interactive shopping, games, content, and do-it-yourself (DIY) videos offer fun and reading pleasure to entice the Canadian Generation Y consumers to retail websites.

Generation Y expect to live a work-life balance lifestyle that is not too work-oriented or too leisure-oriented (Fenich, Scott-Hassell and Hashimoto, 2011; Myers, 2010). They are expected to represent 40 per cent of the Canadian workforce by 2020 (The Public Commission of Canada, 2009) and eventually, 75 per cent by 2028 (ExecuTrade, 2014). This generation is influential as it represents about 30 per cent of the Canadian population and is the single largest segment of the Canadian population (Guffey, Rhodes and Rogin, 2010). Generation Y wants to be active and live a healthy lifestyle (Jones, 2011). They are surrounded by their family members, relatives, friends, and the local community (Marilee, 2011). The results of the interviews suggest the following themes with regard to the Generation $\mathrm{Y}$ and their lives. 


\section{Time Accessing the Internet}

The Internet has become pervasive so it can be connected anywhere and anytime and is slowly becoming connected to physical things (Francesco, Mingozzi and Cao, 2015). Some examples of physical things refer to electric switches that can be monitored and controlled via the Internet.

The favourite time to access the Internet for interviewees is early in the morning and evening. However, interviewees access the Internet at other times according to their commitments and priorities with work and their personal and family schedules. The interviewees read and reply to emails, socialise on social media, and surf the Internet to read about work-related activities and current events. They gather information about products, shopping deals, weather, and restaurants through reviews, news, classified advertisements, historical information, and provincial bylaws. They conduct banking, shopping, and business activities, watch television, and play video games. Retail websites linked to social media, shopping deals, shopping reviews, hashtag news, and games entice more Generation $Y$ consumers.

\section{Types of Search Engines Used}

Google is overwhelmingly preferred by the interviewees because of its excellent search output. Google is now the most widely used search engine in the world and can search for most company websites that sell products or services online (Durica and Svabova, 2015). As the largest search engine in the world, it holds 66 per cent of the market share and receives 3 billion search requests per day (O'Reagan, 2015). In 2014, 90 per cent of Google's revenue was generated from advertisements (Turban, King, Lee, Liang and Turban, 2015).

In a recent study, Google came out at the top among all search engines for utilising natural language search (Hariri, 2013). By moving its own content to the top of its results, Google is generating revenue for its own traffic and, therefore, may create a disadvantage for its competitors (Hazan, 2013). Google's vertical search is not based on meritocracy against its competitors with regard to products or services that companies have developed but rather based on superior exposure.

Search engines, such as Yelp and Expedia, have claimed that Google has shown bias in its vertical search, favouring specialised searches from Google+ and Google Flights on the top of its result pages (Grimmelmann, 2013). Google matches its advertising with keywords when a user keys them to the Google input box. This is in contrast with social media advertisements such as those on Facebook, which are based on Facebook user profiling and the registration of the number of users by clicking on the "Like" button (Minazzi, 2015).

Google offers numerous free services online under the brand names Google Analytics and Google Trends. The basic service of Google Analytics is enabling users to track e-commerce traffic for their websites for free (Boone, Ganeshan and Hicks, 2015). Google Trends offers searches based on the latest information using keywords such as "gift" and "paella" (Boone, Ganeshan and Hicks, 2015) to forecast consumer buying behaviour (Schmidt and Vosen, 2013). Small retailers can use these services to attract the right customers to their websites.

\section{Shop at Specific Retall Websites}

This section focuses on marketing functions instead of user interfaces on a retail website. The interviewees visit or shop at certain retail websites because of the product range offered, ease of navigation, pricing, product information, reviews, service consistency, promotions, product return, transportation cost, convenience, warranties, reputation of retail websites, and reputation of the products.

These attributes that promote Internet commerce are well documented, researched, and supported by Pires, Stanton and Rita (2006) (product range); Chi (2011) (ease of navigation); Bailey, Faraj and Yuliang (2007); McDonald and Ho (2002) (pricing); Dimoka, Hong and Pavlou (2012); Keng, Ting and Cheng (2011) (product information); Chen and Holsapple (2013); Cheung, Lee and Rabjohn (2008); Hung, Chen, and Huang (2014); Asadullah et al. (2019); Paruchuri et al. (2021) (reviews); Huang and Finch (2010) (consistency of service); Siddique and Ahmed (2015); Yousefi and Tang (2012) (promotions); Ahmed and Siddique (2013); Lai, Ulhas and Lin (2012) (product return), Anderson, Simester and Zettelmeyer (2010) (transportation cost); Fan, Lee and Kim (2013); Singh, Bansal and Kaur (2012) (convenience); Yousefi and Tang (2012); Doewes et al. (2021) (warranties); Kim and Lennon (2012); Morrison and Crane (2007); Ahmed and Ganapathy (2021); Khan et al. (2021); Ganapathy, Ahmed and Siddique (2021) (reputation of retail websites); and Jansen, Sobel and Zhang (2011) (reputation of the products).

The best model to explain service quality that is still relevant today is (SERVQUAL) (Ziethaml, Parasuraman and Berry, 1990). Figure 1 below provides a layout of the shop of specific retail websites according to the Six C's model (Context, Condition, Causes, Consequences, Contingencies, and Covariance) (Glaser, 1978). The diagram explains what entices Canadian Generation Y consumers to visit and shop at Canadian small business retail websites based on the analysis of the interviews. This section excludes data relating to security and privacy as this will be covered in another section.

To utilise the $6 \mathrm{Cs}$ model, the following assumptions have been made. The context of this study is why Canadian Generation Y consumers visit and shop at only certain Canadian small business retail websites. The condition is based on certain reasons why Canadian Generation Y consumers visit and shop at specific Canadian small business retail websites. The causes are the reasons for 
visiting and shopping at certain Canadian small business retail websites. The consequences are the effect of these causes. Covariance are the strategies that are applicable based on the causes. Lastly, contingencies are the application of strategies for each of the causes to encourage Canadian Generation $\mathrm{Y}$ consumers to visit and shop.

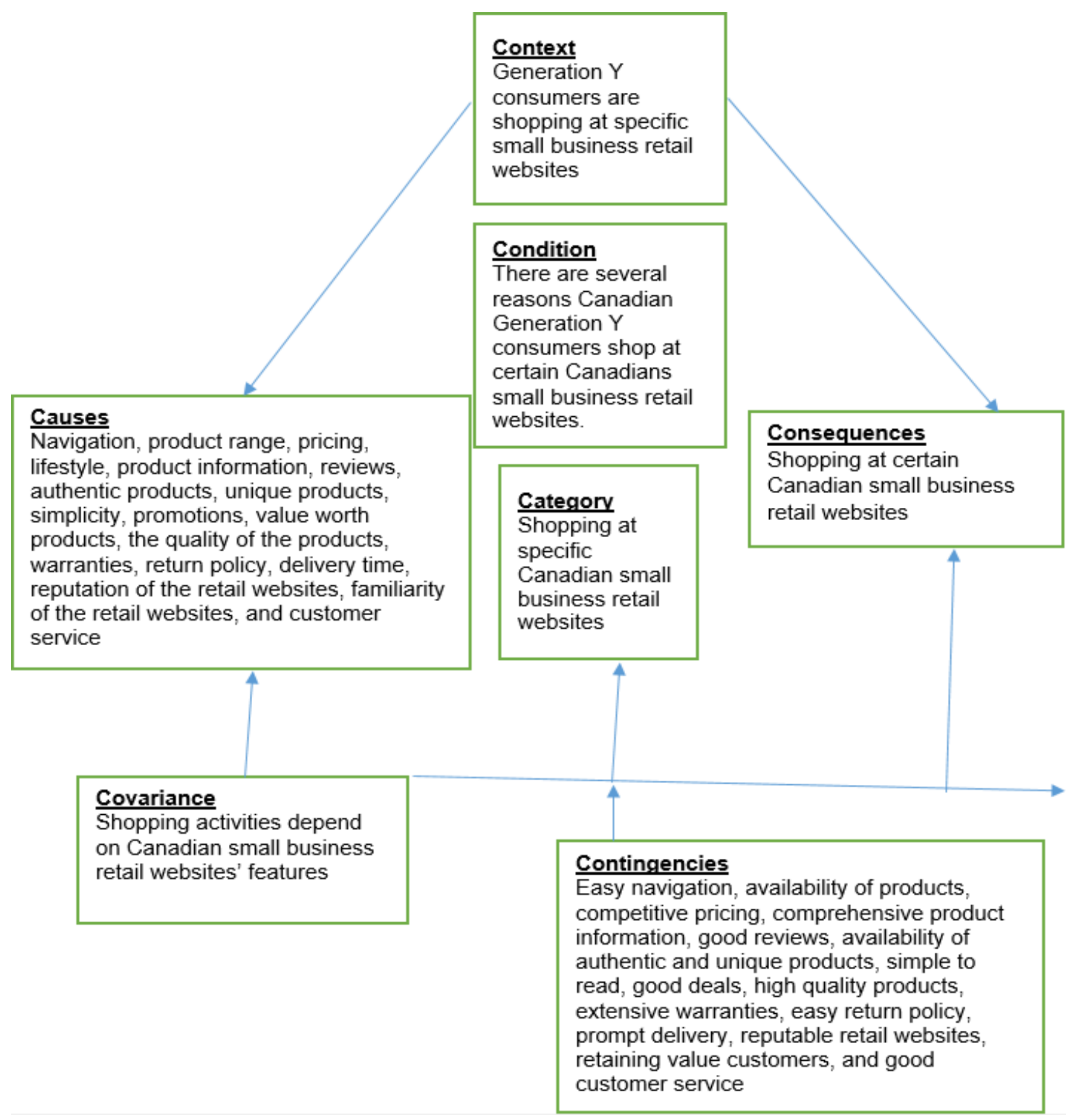

Figure 1: Shopping at Specific Retail Websites

\section{Context}

The context is based on why Canadian Generation Y consumers shop at only certain Canadian small business retail websites.

\section{Condition}

The conditions are certain reasons as to why Canadian $Y$ consumers only shop at specific Canadian small business retail websites. 


\section{Causes}

The causes for Canadian Generation $\mathrm{Y}$ consumers shopping at certain specific retail websites were revealed to be navigation, product range, pricing, product information, reviews, authentic products, unique products, simplicity, promotions, value worth products, the quality of the products, warranties, return policy, delivery time, reputation of the retail websites, familiarity of the retail websites, and customer service. Authentic products, unique products, and the quality of the products were grouped with the product as they are related. Value-worth products and promotions were added to the topic of pricing as they are also related.

Navigation: Ease of navigation enables quick search for information in a meaningful manner. This, therefore, increases the Performance Expectancy. Performance Expectancy in this research has been found to be statistically significant. Cluttered navigation design makes it more difficult for a user to surf, which may mean that they may not return to the website. Consumers do not like to be pursued or be hindered by pop-up windows that ask questions before the consumer can initiate the next process. A5 mentions that "It is very frustrating when I am interrupted with pop-ups when I am trying to shop. I am good with not having pop-ups." He feels that pop-up messages that hinder another action are annoying. There is a need to simplify navigation wherever necessary to complete a purchase task. Any unnecessary hindrance is not convenient for navigation and does not entice consumers to the retail websites.

Product Range: With a wider product range, a consumer will have a better product fit and, therefore, there is a higher likelihood of increased purchases. Small business retailers may not be able to have an extensive choice of products as they may not be able to afford to carry such a range, especially where the products must be purchased beforehand. Many small business retailers are specialising in specific product ranges when selling online.

Pricing: Canadian Generation Y consumers expect to see online prices that are competitive. Depending on the products or services, this can be assessed based on cost leadership, differentiation, and/or focus market strategy. As the world's economy becomes more globalised and the Internet transcends time and location, the pricing of products is responding to an increased competition by becoming more competitive with regard to value consideration. Profit margins without value adding have dropped. A4 stated, "Not all the websites have similar price. Some of the prices differ a lot." He admits to comparing product prices between large and small retailers. Having analysed these factors, it was found that pricing being based on giving discounts to those who buy in volume is important for consumers. Purchases need to be tracked so that consumers will get the benefits of being loyal when frequently shopping at the retail website and buying in volume. This could even be in the form of better services like offering a tracking facility after consumers register with the retailer.

Lifestyle: Smaller online retailers can offer better aftersales service for local consumers because of their proximity. This may include maintenance and repairs where the retail owners have the expertise. Many Canadian Generation $Y$ consumers are juggling going to work or school with their personal lives. For example, A28 is rushed for time when she shops online. Canadian small businesses, by offering free delivery service, connect well with local consumers. These retailers are also sometimes manufacturers and, consequently, are able to offer better synergy by specialising while offering competitive pricing.

Product Information: By having a comprehensive list of essential product information online, consumers are in a position to make better purchasing decisions. The product information comes in the form of pricing, description, size, weight, colour, quantity, usage, texture, and terms and conditions of sale. A5 expects important information about the product to be provided but not unnecessary information that elaborates without adding any value. By allowing consumers to register their details and preferences online, new product information can also be emailed and shown on social media. Offering product trials may help to convince consumers to purchase the new product owing to enhanced reliability.

Reviews: The inclusion of reviews can create credibility for retail websites. A3 and A12 find reviews to be important before they make a purchasing decision. On the other hand, there are some issues for consumers relating to the value of reviews. Reviews may not always be impartial and may only serve the vested parties. Any individual can use a pseudonym to give a review and an unscrupulous reviewer may write something positive in support of a retailer, even if it may not be so. There is a limit, however, to how far such dishonesty works. The quality of a product would "speak for itself" and sooner or later, consumers would express their disappointment, balancing false reviews with more credible ones.

Products: Canadian Generation Y consumers expect the products sold online to be authentic or original with the right quality. A20 explained that "I only shop online as the last resort because of convenience." 
Just like anybody else, they are concerned with products sold online that cannot offer "feel and touch". Unique products that cannot be found in a brick and mortar environment may be sought online. The quality of these products sold online is significant. For example, A20 finds it easier to find odd sizes or smaller shirts online. Canadian Generation Y consumers expect different brands and have high expectations. The use of the Internet as a marketing gateway opens opportunities that were never recognized three decades ago. Online businesses can be established not just by merely selling a tangible products per se but also by offering added services. This availability includes giving tutoring or a customised programme offered through a multimedia application.

Warranties: Since the Internet is an expanse of virtual space with many unknowns, warranties may improve confidence for Canadian Generation Y consumers who are considering online purchasing. By offering a warranty, a binding legal contract exists between the retailer and consumer. Consumers are more convinced of the after-sales service, especially if it is an international brand that has many support centres in Canada. For example, A16 expects easy parts replacement. However, in the virtual environment, it still may be more difficult to impose the warranty if there is any contradiction from the retailer.

Return Policy: Canadian Generation Y consumers will feel less risk with a purchase online if there is a return policy. The return policy is a legally binding contract that must be enforced. Without a clear return policy, a lack of confidence may be created in the consumer, particularly for first-time users. A8 does not like to have to pay the transportation charges for returning a product as it increases the price and the uncertainty of the product. If there is a defect with the product or delivery of a wrong product, which is the retailer's fault, it is only ethical to receive a replacement and free return without any charges incurred. That is why, the return policy should not leave any "grey" areas to identify who is at fault. It must identify if the damage relates to the consumer or retailer or when it is a manufacturer defect.

Delivery Time: Many businesses that extend to the Internet seem to focus on delivery. Delivery time should be prompt and according to the promised date. When delivery times are met consistently, consumers do not have to worry about not receiving their products on time. A8 mentioned from his experience of buying from large retailers that they tend to be slow in delivering. Late delivery may force the Canadian Generation $\mathrm{Y}$ consumers to shop elsewhere and they may not return to the retail website again. Therefore, when a retailer informs the delivery date of the product, the consumer can decide whether to continue or not with the order.

Reputation of Retail Websites: The reputation of a website may be enhanced by adding additional services. Offering discounts for regular consumers, depending on the sales amount, may draw the consumer to continue to shop at such websites or recommend them. Other incentives would include making consumers aware of new product availability by email and/or creating events in conjunction with product launches. Canadian Generation Y consumers are more likely to shop at retail websites they are more familiar with. According to them, it will save time and reduce risk. A8 and A9 want to continue shopping at retail websites they are familiar with and where they have had a positive experience. As A15 puts it, "Once I am comfortable with a website, I do not want to change, unless there is a major issue because of time". According to A15 and A27, familiarity with a retail website saves him time and gives him the confidence to continue to purchase from the same retail website.

Customer Service: Having good customer service will enhance the usability of the retail websites. Here, the unimportance of trust can also be mitigated. Customer disputes should be resolved as soon as possible so that consumers are convinced that the retail website is a legitimate and professionally managed one. A16 expects a fast response time, within a day, for any enquiries. A17 said, "Canada is a large country. We need good online support." If not, the main concern is that the customer may not visit the retail website again and move on to another website entirely. Despite the relevance of trust described in the literature relating to online purchasing, it is seen in the qualitative data that there are significant factors that can mitigate the significance of trust for Generation Y consumers. Generation $Y$ consumers can mitigate their concerns by patronising websites that have a reputation for consistently efficient delivery. Further, by relying on the good reputation of retail websites and their good customer service, the importance of trust can be fulfilled.

\section{Category}

Category is classified as shopping at specific Canadian small business retail websites by Canadian Generation $\mathrm{Y}$ consumers.

\section{Consequences}

What causes the interviewees to visit and shop at certain Canadian small business retail websites can also increase 
their frequency of visiting and shopping at the existing and new websites.

\section{Covariance}

Shopping activities by Canadian Generation Y consumers depend on the features of Canadian small business retail websites.

\section{Contingencies}

Contingencies would depend on the ease of navigation, the availability of products, competitive pricing, comprehensive product information, good reviews, availability of authentic and unique products, being simple to read, offering good deals, high quality products, extensive warranties, an easy-return policy, prompt delivery, reputation of the retail websites, capability to retain valued customers, and good customer service.

\section{Security And Privacy on the InTERnet}

This section focuses on the security and privacy aspects of the Internet. Although security and privacy have not been found to be statistically significant in the quantitative analysis of this study, these factors have been expressed as a concern for many individuals in various degrees. The qualitative data supports the idea that security and privacy are of concern for many of the target audience, particularly in relation to payments. Security and privacy are qualitatively expressed as a top priority for some Generation Y contributors.

This section responds to why security and privacy does not affect Canadian Generation Y consumers' use of the Internet. Unfortunately, the Internet itself does not always provide security at the network level (Hill, 2014). Security should be provided by the end-devices where the computers are connected to the network. The lack of compulsory security on the Internet has created both positive and negative outcomes. More innovations are being created to remedy this constraint.

The lack of security control has led to the creation of online black markets for illegal products and cyberwars. If security incidents are not well contained, the trust between vendors and customers could be eroded and lost (Nazareth, 2014). This is the reason Canada's cybersecurity is based on the principles of creating awareness among Canadians about online security, providing security for government computer systems, and private sector partnerships and cooperation (Deibert, 2012). The Royal Canadian Mounted Police will be establishing a new highly-specialised unit to fight the rapidly increasing local and international cybercrime (Seglins, 2015). Top Internet controls could come in the form of system monitoring, authentication, encryption, network segmentation, and system testing (Tankard, 2015).

Figure 2 below shows the Six C's Model that includes Context, Condition, Causes, Category, Consequences, Covariance, and Contingencies (Glaser, 1978). The diagram below explains the security and privacy aspect of online shopping for Canadian Generation Y consumers.

The quantitative analysis of this study revealed that security and privacy are not statistically significant. Canadian Generation Y consumers believe they can mitigate security and privacy risks with various steps, such as complex passwords, two-factor authentication, updating the system with the latest anti-virus software, and carrying out periodic computer maintenance. The causes are mitigating the risks of using complex passwords, two-factor password, anti-virus software, and computer maintenance. The conditions are based on using complex passwords, two-factor password, virus software, and computer maintenance because of which the Canadian Generation Y consumers are unconcerned about security and privacy on the Internet. The category is the unimportance of security and privacy on the Internet. The consequences are the effect of the causes i.e., the result being that Canadian Generation Y consumers are unconcerned about the security and privacy risks. Covariance is based on the strategies to apply on the causes. Finally, contingencies are applying strategies for each of the causes to mitigate the risks associated with Canadian Generation Y consumers' use of the Internet. The contingencies are based on creating complex passwords, two-factor password authentication, using the latest anti-virus software, and periodic computer maintenance.

\section{Context}

This context is based on the lack of influence of security and privacy over Canadian Generation Y consumers' use of the Internet.

\section{Condition}

There are certain conditions, such as complex passwords, two-factor password, anti-virus software, and computer maintenance that need to be in place for Canadian Generation $Y$ consumers, because of which they are not influenced by security and privacy concerns while using the Internet. 


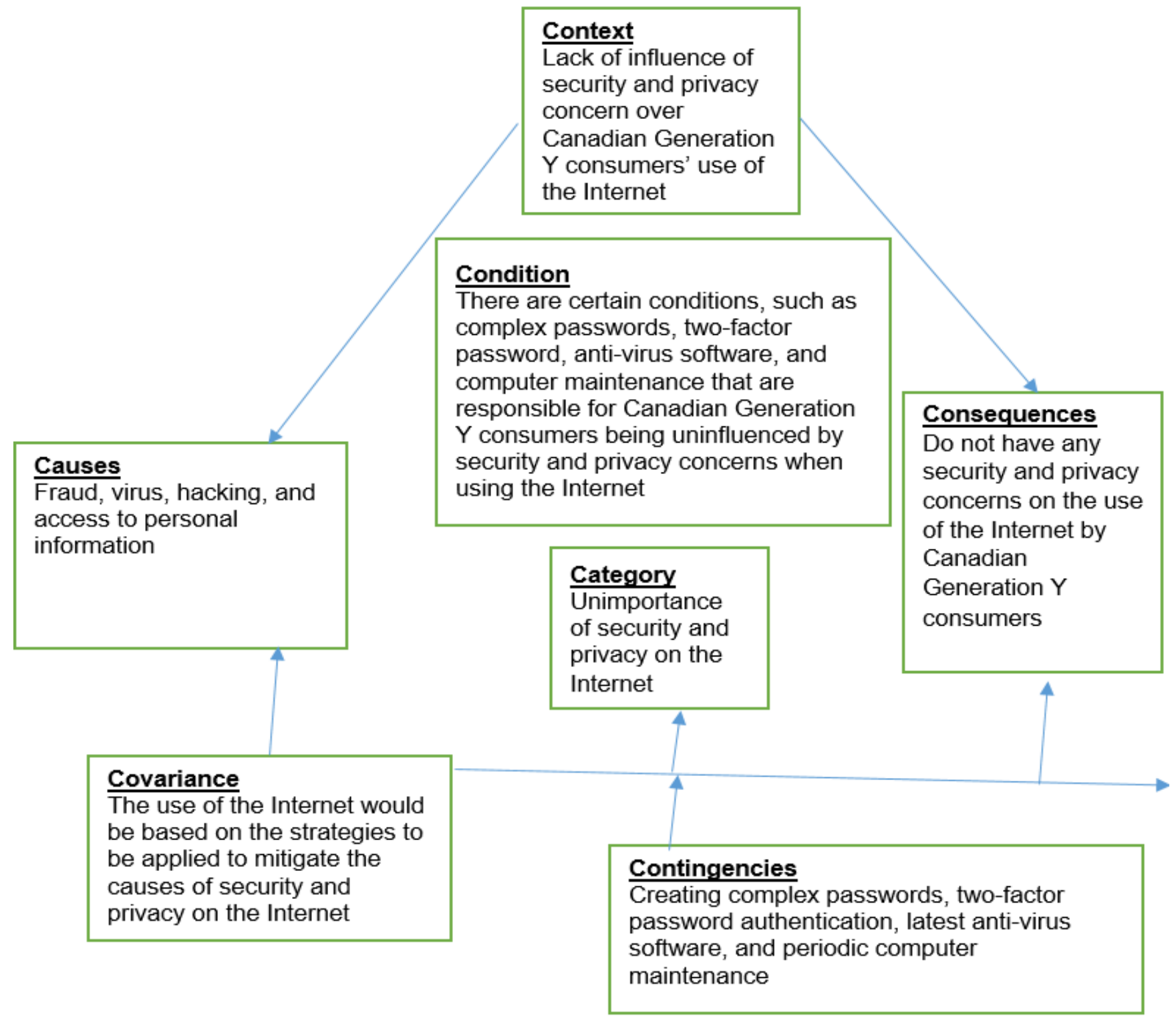

Figure 2: 6 Cs of Security and Privacy on the Internet

\section{Causes}

The causes that do not influence the use of Internet are mitigating the risk of fraud, access to personal information, and the threat of hacking and viruses.

\section{Fraud Prevention, Access to Personal Information, Hacking, and Viruses}

Fraud prevention can mitigate the security and privacy risks of the Internet. Consumers need to be aware of the risks and how to mitigate them. The issue with the Internet is that nobody owns it and it is not practically possible for it to be 100 per cent secure, although it is possible theoretically. The Internet must adopt and adapt to technological and external social changes. As the Internet becomes more complex with an increased number of users, greater data, and more integration into a complex IT system, there is a

balancing act to consider between security and usability.

With the increase in connection of devices by the means of the Internet of Things (IoT), there will be even more exposure to security and privacy concerns because of the increase in the number of entry points. The establishment of this technology enables electronic and electrical appliances to be monitored and controlled via the Internet. While consumers expect processes to become more efficient, security protocols are antagonistic to this. For this reason, there is no Internet Service Provider (ISP) that can guarantee a 100 per cent Internet uptime. Some may not even have the knowledge and experience to mitigate such risks. As such, there is a need to balance the security aspects with efficiency. Stringent security validation, firewalls, and updated anti-virus software should be in place. 
Prior to the introduction of the Internet, credit card transactions were used in a brick and mortar environment. The risk of credit card violation in a brick and mortar environment is uncommon and unjustified, leaving the culpability of a retail store open. By comparison, the level of risk for a security and privacy breach over the Internet seems to be at a level whereby Internet use is still manageable.

Hacking can come in the form of phishing emails as well. It has become so sophisticated as to address the person directly and the best remedy is to not open an email sent by a person that one is not familiar with. To prevent hacking, repeatedly using the same password must be avoided. Increased complexity of passwords can be utilised by adopting a combination of upper and lower-case alphabets, numbers, and symbols. By using two-factor authentication, a text code can be sent to the app or mobile phone to be used for logging in. This provides another layer of security as a text code is generated from another device. The password should also not be shared with another person. These techniques can reduce the likelihood of hacking.

There is a need to utilise the latest software updates and fixtures to address any shortcomings in anti-virus, operating system, search engine, and application software. For example, always accessing secure online services for email, banking, shopping, and social media by making sure that there is a padlock indicator at the beginning of the Uniform Resource Locator (URL), such as "https://". Logging out securely is a good practice to avoid hacking. Digital signatures can be used to confirm the authenticity of a transaction. There is a need to carry out periodic computer maintenance, such as removing files from the empty bin. Default firewalls must be turned on and basic cleaning of the computer hardware and software should be carried out.

Despite such measures, there are certain security and privacy concerns in relation to access to control. For example, liberty to surf independently may not be the case on the Internet. When somebody surfs and visits a website, it can appear harmless but this may not be the case. By accessing a certain website, a user may be redirected to another website by force, without the option of redirecting, for example. They can only click on the targeted webpage. In this matter, the researcher feels that a user should not be redirected without him or her knowing where the person is surfing. The websites that legitimise such actions do not help mitigate the security and privacy concerns of consumers.

By exercising what has been discussed, the security and privacy risks on the Internet can be mitigated to a certain level. As consumers are an integral part of the Internet system, they do have a role to play when using the Internet. Although the Internet is not perfect, it certainly enables small retailers to extend their reach far and wide. The Internet has become an integral part of marketing strategies for small business retailers.

\section{Category}

This category is called the unimportance of security and privacy on the Internet.

\section{Consequences}

The consequences are based on the question about why Internet security and privacy are not a concern to Canadian Generation Y consumers.

\section{Covariance}

Covariance is based on the strategies to apply to mitigate the causes of security and privacy on the Internet.

\section{Contingencies}

The contingencies are based on creating complex passwords, two-factor authentication, latest virus software, maintenance, and good security and privacy policy.

\section{Discussion OF STUDY Findings}

This section discusses the findings of this study with relation to the research question. The data collected through the questionnaires and personal interviews has been discussed in this section to provide a better understanding for answering the research question. The results are compared with previous research from review of related literature in terms of adoption matters. Research Question is explored to describe how Canadian Generation Y consumers carry out their activities on the Internet.

According to the data collected through the questionnaire survey, 60 per cent of the respondents spent 1 to 100 hours per month on the Internet on an average. About threequarters of the respondents spent between 1 to 20 per cent of their Internet time in shopping. Ninety-three per cent of the respondents chose Facebook as the main choice for social media while YouTube came in second at 87 per cent.

Canadian Generation $\mathrm{Y}$ is a very socially active generation. They perceive life to be lived to the fullest, by spending quality time with their families, loved ones, and friends, enjoying what they like to do most, and have a work-life balance. This generation is accessing the Internet at their homes, offices, and vehicles, at any time as the Internet transcends time and place. Google is the most preferred search engine because of its incomparable search results. The attributes that lure them to the retail websites are product variety, ease of use, price, product attributes, customers' feedback, service reliability, convenience, promotions, item return policy, warranties, free transportation, and the reputation of retail websites and the products. 
According to the interview, it was discussed that there is no such thing as having an Internet environment that is 100 per cent free of security breaches with no violation of individual privacy. After all, the purpose of the Internet is communication. The irony is that the Internet is leading to its own weaknesses by exposing and subjecting the viewers to read information that may or may not be true, without proper validation. At the same time, new viruses are being developed all the time and no anti-virus product has the remedy to remove all kinds of viruses immediately. These products try to develop an anti-virus software as soon as possible in order to remove a new virus, thereby leaving machines susceptible to cyber-attacks.

\section{CONCLUSION}

This research raises awareness about the internet behaviour of the Canadian $Y$ generation by demonstrating how they use the internet. As a result of expanding urbanization in Canada, Canadians are increasingly pressed for time in the midst of the hustle and bustle of daily life. They are able to avoid the time limitations associated with driving to and from brick and mortar shops by shopping online.

This can be explained by the fact that, despite the fact that Canadian Generation Y consumers lack confidence in the security and privacy protection provided by Canadian small company retail websites, this may not discourage them from continuing to shop online. The following measures should be implemented to improve the security and privacy of retail websites: identification and authentication, system monitoring and testing, encryption, system testing, and network segmentation (Tankard, 2015). Canadians are also purchasing online on typical sales promotional days such as Boxing Day and Black Friday, according to the Canadian Internet Retailer (The Canadian Press, 2015). As a result, new opportunities for online retail promotions arise as a result of these events.

This shows that the use of the Internet may be out of reach for many Canadian Generation Y'ers, based on the insignificance of the Price Value (PV). Many Canadian youngsters are unemployed or underemployed, and many of them are still living at home with their families. Internet rates in Canada are still high, and Canadians pay an average of $\mathrm{C} \$ 100$ to $\mathrm{C} \$ 212$ per month on communication services such as phone and Internet charges, according to Statistics Canada (Nowak, 2015). Because the cost of accessing the Internet is still prohibitively expensive, the Canadian government should allow new Internet Service Providers (ISPs) to enter the market in order for these new players to be able to increase the length of the spectrum available for distribution. As a result of the growth in competition, it is believed that the rates for using the Internet would be decreased.
According to the qualitative data acquired, the reasons for this are that the reputation of retail websites, certification, and security and privacy policies are all able to minimize the security and privacy risks for Generation $Y$ respondents, which is consistent with the findings.

Although trust has been suggested as a predictor of Internet website use by Generation $Y$ customers in prior work, a rigorous quantitative process has demonstrated that it is inconsequential, as explained in this critical assessment of the literature. As a result, it raises the question, "Why does trust have no effect on the behaviour of Canadian Generation Y consumers when they visit the websites of Canadian businesses?" Further qualitative interviews reveal that the reputation of retail websites, delivery time, pricing, product description, privacy policy, security, products, online transactions, information formation, website speed, terms and conditions, warranty, third-party certifications, discounts, public relations, promotions, publicity, and advertising are all factors that contribute to Canadian Generation $Y$ consumers' lack of concern about trust in the marketplace.

\section{REFERENCES}

Ahmed, A. A. A., \& Ganapathy, A. (2021). Creation of Automated Content with Embedded Artificial Intelligence: A Study on Learning Management System for Educational Entrepreneurship. Academy of Entrepreneurship Journal, 27(3), 1-10, https://doi.org/10.5281/zenodo.4973057

Ahmed, A. A. A., \& Siddique, M. N.-E.-A. (2013). Internet Banking Espousal in Bangladesh: A Probing Study. Engineering International, 1(2), 93-100. https://doi.org/10.18034/ei.v1i2.211

Anderson, E. T., Simester, D. and Zettelmeyer, F. (2010). Internet channel conflict: Problems and solutions, Review of Marketing Research, 7(1), pp. 63-92.

Asadullah, A., Juhdi, N. B., Islam, M. N., Ahmed, A. A. A., \& Abdullah, A. (2019). The Effect of Reinforcement and Punishment on Employee Performance. ABC Journal of Advanced Research, 8(2), 47-58. https://doi.org/10.18034/abcjar.v8i2.87

Bailey, J. P., Faraj, S. and Yuliang, Y. (2007). The road more travelled: Web traffic and price competition in internet retailing, Electronic Markets, 17(1), pp. 56-67.

Boone, T., Ganeshan, R. and Hicks, R. L. (2015). Incorporating Google trends data into sales forecasting, Foresight: The International Journal of Applied Forecasting, 38, pp. 9-14.

Chen, L. and Holsapple, C. W. (2013). E-business adoption research: State of the art, Journal of Electronic Commerce Research, 14(3). pp. 279-286.

Cheung, C. M. K., Lee, M. K. O. and Rabjohn, N. (2008). The impact of electronic word-of-mouth: The adoption of 
online opinions in online customer communities, Internet Research, 18(3), pp. 229-247.

Chi, H. H. (2011). Interactive digital advertising vs. virtual brand community: Exploratory study of user motivation and social media marketing responses in Taiwan, Journal of Interactive Marketing, 12(1), pp. 4461.

CIRA Factbook (2014). The Canadian Internet, CIRA. [Online accessed, 20th March, 2016].

Deibert, R. (2012). Distributed security as cyber strategy: Outlining a comprehensive approach for Canada in cyberspace, Canadian Defence and Foreign Affairs Institute, Ottawa, Canada.

Dimoka, A., Hong, Y. and Pavlou, P. A. (2012). On product uncertainty in online markets: Theory and evidence, MIS Quarterly, 36(2), pp. 395-426.

Doewes, R. I.; Ahmed, A. A. A.; Bhagat, A.; Nair, R.; Donepudi, P. K.; Goon, S.; Jain, V.; Gupta, S.; Rathore, N. K.; Jain, N. K. (2021). A regression analysis based system for sentiment analysis and a method thereof. Australian Official Journal of Patents, 35(17), Patent number: 2021101792. https://lnkd.in/gwsbbXa

Durica, M. and Svabova, L. (2015). Improvement of company marketing strategy based on Google search results analysis, Procedia Economics and Finance, 26, pp. 454460.

ExecuTrade (2014). How millennials are reshaping small business in Canada, ExecuTrade, March 11th, 2014. [Online accessed, 16th March, 2014]. http://www.executrade.com/blog/how-millennialsare-reshaping-small-business-incanada/\#axzz2w9iiZDPH

Fan, Q., Lee, J. Y. and Kim, J. I. (2013). The impact of website quality on flow-rated online shopping behaviours in C2C e-marketplaces: A cross-national study, Managing Service Quality, 23(5), pp.364-387.

Fenich, G. G., Scott-Hassell, S. and Hashimoto, K. (2011). An investigation of technological uses by different generations as it relates to meetings and events: A pilot study, Journal of Convention and Event Tourism, 12, pp. 53-63.

Francesco, M. D., Mingozzi, E. and Cao, J. (2015). Special issue on the Internet of things, Pervasive and Mobile Computing, 20, pp. 82-83.

Ganapathy, A., Ahmed, A. A. A., Siddique, M. NEA., (2021). Easy URLs in the Content Management System with Crawlers for Added Security. Academy of Marketing Studies Journal, 25(4), 1-10. https://doi.org/10.5281/zenodo.5002945

Glaser, B. G. (1978). Theoretical sensitivity: Advances in the methodology of grounded theory. Sociology Press, Mill Valley, California.
Gomez-Herrera, E., Martens, B. and Turlea, G. (2014). The drivers and impediments for cross-border ecommerce in the EU, Information Economics \& Policy, 28(C), pp. 83-96.

Grimmelmann, J. (2013). What to do about Google?, Communications of the ACM, 56(9), pp. 28-30.

Guffey, M. E., Rhodes, K. and Rogin, P. (2010). Business communication: Process and product. Third Brief Canadian Edition, Nelson Education, USA.

Hariri, N. (2013). Do natural language search engines really understand what users want?, Online Information Review, 37(2), pp. 287-303.

Hazan, J. G. (2013). Stop being evil: A proposal for unbiased Google search, Michigan Law Review, 111(5), pp. 789820.

Hill, R. (2014). The internet, its governance, and the multistakeholder model, Info, 16(2), pp. 16-46.

Huang, X. and Finch, B. J. (2010). Satisfaction and dissatisfaction in online auctions: an empirical analysis, International Journal of Quality Reliability Management, 27(8), pp. 878-892.

Innovation, Science and Economic Development Canada (2016). Key small business statistics, Government of Canada, June.

Jansen, B. J., Sobel, K. and Zhang, M. (2011). The brand effect of key phrases and advertisements in sponsored search, International Journal of Electronic Commerce, 16(1), pp. 77-106.

Jones, D. (2011). It's Evolution, Baby, Benefits Canada.

Keng, C., Ting, H. and Cheng, Y. (2011). Effects of virtualexperience combinations on consumer related "sense of virtual community", Internet Research, 21(4), pp. 408-434.

Khan, W., Ahmed, A. A. A., Vadlamudi, S., Paruchuri, H., Ganapathy, A. (2021). Machine Moderators in Content Management System Details: Essentials for IoT Entrepreneurs. Academy of Entrepreneurship Journa, 27(3), 1-11. https://doi.org/10.5281/zenodo.4972587

Kim, J. and Lennon, S. J. (2012). Electronic retailing and service quality, service management, The New Paradigm in Retailing.

Lai, J. Y., Ulhas, K. R., and Lin, J. D. (2014). Assessing and managing e-commerce service convenience, Information Systems Frontiers, 16(2), pp. 273-289.

Marilee, (2011). Generation Y: Challenging employers to provide balance. Who are Generation $Y$ and do employers and managers in the non-profit sector really need to fear them?, BC Council for Families. [Online accessed, 2nd January,

2015].

http:/ / www.bccf.ca/all/resources/generation-ychallenging-employers-provide-balance 
McDonald, R. P. and Ho, M. H. R. (2002). Principles and practice in reporting statistical equation analyses, Psychological Methods, 7(1), pp. 64-82.

McKinnon, M. (2013). Help for the 54\% of Canadian small businesses without a website (Statistics), Canadian's Internet Business, March 4th. [Online accessed, 16th March, 2014]. http://canadiansinternet.com/helpfor-the-54-per-cent-of-canadian-small-businesseswithout-a-website-statistics/

Minazzi, R. (2015). Social media impacts on travel suppliers: Social media marketing, in Social Media Marketing in Tourism and Hospitality, Springer International Publishing, Switzerland.

Morrison, S. and Crane, F. G. (2007). Building the service brand by creating and managing an emotional brand experience, Journal of Brand Management, 14, pp. 410211.

Myers, K. (2010). Millennials in the workplace: A communication perspective on millennials' organizational relationships and performance, Journal of Business and Psychology, 25(2), pp. 225-238.

Nazareth, J. C. D. L. (2014). Repairing trust in an e-commerce and security context: An agent-based modelling approach, Information Management $\mathcal{E}$ Computer Security, 22(5), pp. 490-512.

Nowak, P. (2015). Internet, phone bills in Canada too high, says consumer study, CBC News. [Online accessed, 27th December, 2015]. http://www.cbc.ca/news/business/internet-phonebills-in-canada-too-high-says-consumer-study$\underline{1.3005282}$

O'Reagan, G. (2015). Pillars in computing, Springer International Publishing, Switzerland.

Paruchuri, H.; Vadlamudi, S.; Ahmed, A. A. A.; Eid, W.; Donepudi, P. K. (2021). Product Reviews Sentiment Analysis using Machine Learning: A Systematic Literature Review. Turkish Journal of Physiotherapy and Rehabilitation, 23(2), 2362-2368. https://doi.org/10.5281/zenodo.5534344

Peng, H., Xu, X. and Liu, W. (2011). Drivers and barriers in the acceptance of mobile payment in China, Communications in Information Science and Management Engineering, 1(5), pp. 73-78.

Pires, G. D., Stanton, J. and Rita, P. (2006). The internet, consumer empowerment and marketing strategies, European Journal of Marketing, 40(9/10), pp. 936-949.
Seglins, D. (2015). New RCMP cyber unit to target global hackers, online scammers, $C B C$ News, December 2nd [Online accessed, 2nd December, 2015]. http://www.cbc.ca/news/canada/rcmp-cyber-unittarget-hackers-online- scammers-1.3346915

Siddique, M. N. \& Ahmed, A. A. A. (2015). Congruence of Competitive Advantage and Transfer Pricing: A Study on Selected MNCs Operating in Bangladesh. Asian Accounting and Auditing Advancement, 5(2), 119-126. https://doi.org/10.5281/zenodo.5562717

Singh, D., Bansal, M., and Kaur, N. (2012). Internet Retailing - New Era of Marketing, International Journal of Marketing and Technology, March 2, 2(3), pp. 15-23.

Statistics Canada (2013). Canadian internet use survey, 2012. [Online accessed, 31st January, 2016]. http://www.statcan.gc.ca/dailyquotidien/131126/dq131126d-eng.htm

Statistics Canada (2014). Retail at a glance: E-commerce sales, 2012. [Online accessed, 31st January, 2016]. http://www.statcan.gc.ca/dailyquotidien/140708/dq140708b-eng.htm

Tankard, C. (2015). The security issues of the Internet of Things, Computer Fraud E Security, 2015(9), pp. 11-14.

The Canadian Press (2015). Canadian shoppers cash in on Boxing Day bargains, online and in stores. [Online accessed, 11th January, 2016]. http://www.cbc.ca/news/business/boxing-dayshopping-1.3380894

The Public Commission of Canada (2009). Emerging trends affecting the Public Service Commission and the Public Service Employment Act, September. [Online accessed, 13th October, 2015]. http://www.psc-cfp.gc.ca/abtaps/rprt/psea-lefp/trends-tendances/trendstendances-eng.pdf

Turban, E., King, D., Lee, J. K., Liang, T. P. and Turban, D. C. (2015), Marketing and advertising in e-commerce, Springer International Publishing, Switzerland.

Yousefi, A. and Tang, J. (2012). E-commerce: Consumer online shopping in Canada, Proceedings of the Contemporary Research on E-business Technology and Strategy Communications in Computer and Information Science, pp. 1-14.

Ziethaml, V. A., Parasuraman, A. and Berry, L. L. (1990). Delivering quality service: balancing customer perceptions and expectations, The Free Press, New York, NY.

$$
--0--
$$

